SYLWIA JASKULSKA

Uniwersytet im. Adama Mickiewicza

w Poznaniu

\title{
RYTUALNE I NIERYTUALNE OBLICZE „FALI” W SZKOLE
}

\begin{abstract}
Jaskulska Sylwia, Rytualne i nierytualne oblicze "fali" w szkole [The Ritual and Non-ritual Aspects of Hazing at School]. Studia Edukacyjne nr 43, 2017, Poznań 2017, pp. 113-128. Adam Mickiewicz University Press. ISSN 1233-6688. DOI: 10.14746/se.2017.43.7

In the paper I ask whether the similarities between the institutional hazing and tribal rites of initiation, pointed to by authors who describe this phenomenon, make it possible to talk about a ritual character of the brutal phenomenon of how freshmen are treated by older students, and if they do, then how can it translate into potential preventive measures. I discuss this issue based on the example of hazing at school. Having chosen the distinctive features of the rites of passage as my point of reference, I refer to school hazing as a pseudo-rite and I recommend taking into account its ritual character and the non-ritual objectives it completes in the preventive and repair measures at school.
\end{abstract}

Key words: rite of passage, initiation, hazing at school, aggression at school

Autorzy analizujący zjawisko „fali” w różnych instytucjach często odnoszą swoje rozważania do teorii rytuałów przejścia, czy konkretniej - rytuałów inicjacyjnych. W tekście stawiam pytanie, czy podobieństwa obu zjawisk, które towarzyszą wchodzeniu nowicjuszy do jakiejś grupy pozwalają na utożsamianie „fali” z rytuałami inicjacyjnymi? Uczynienie próby odpowiedzi na to pytanie celem tekstu pisanego przez pedagożkę wymaga dopowiedzenia. Zjawisko "fali” i jego rytualne konotacje stały się przedmiotem namysłu pedagogów, nie tylko pracujących w obszarze resocjalizacji, bowiem "fala”, na wzór wojskowej, zagościła także w szkołach oraz innych placówkach i organizacjach edukacyjnych. Odpowiedź na pytanie, czy szkolna „fala” ma rzeczywiście charakter rytualny zdaje się być ważna, bowiem świadomość natury tego zjawiska, jego przyczyn i znaczenia, jakie nadają mu uczniowie pozwoliłaby w najpełniejszy sposób przeciwdziałać 
agresji, która jest jej stałym elementem. Zakładam zatem, że analiza cech dystynktywnych rytuałów przejścia, które znamy z opracowań antropologów i porównanie z nimi szkolnej "fali" może wskazać możliwe drogi radzenia sobie $\mathrm{z}$ tym problemem w szkołach.

W ujęciu ojca tego pojęcia - Arnolda van Gennepa, rytuał przejścia to „sekwencje obrzędowe, które towarzyszą przechodzeniu z jednego stanu do innego, z jednego świata (w ujęciu kosmicznym lub społecznym) do drugiego" $^{\prime 1}$. W społecznościach plemiennych, o których pisał folklorysta, ze zmianą statusu jednostki zawsze były powiązane rytuały. Przykładem mogą być obrzędy wchodzenia w dorosłość (rytuały inicjacyjne) chłopców. Poddawani przez starszyznę wioski różnym próbom młodzieńcy stawali się mężczyznami. Opisem takich prób rozpoczęłam ten tekst. Van Gennep wyróżnił trzy fazy rytuału2: fazę wyłączenia (preliminarna), przejściową (liminalną) i włączenia (postliminalna) $)^{3}$. Na przykład, w niektórych społecznościach plemiennych kobieta zachodząca w ciążę była odłączana od starego porząd$\mathrm{ku}$ i statusu, czasem fizycznie wręcz odseparowywana, by trwać $\mathrm{w}$ fazie przejściowej, dla której charakterystyczny jest brak statusu (już nie "tam”, jeszcze nie "tu"), zawieszenie praw i obowiązków ${ }^{4}$. Poród włączał ją na nowo do społeczności, ale już w innej roli - roli matki. W przypadku rytuałów inicjacyjnych, które są przedmiotem namysłu w tym tekście, szczególnie ważna była faza liminalna. To podczas jej trwania adepci doświadczali „rytualnej śmierci". Jak pisze Mircea Eliade,

centralny moment każdej inicjacji stanowi ceremonia symbolizująca śmierć neofity i jego powrót pośród żywych (...). Aby stary świat mógł zostać stworzony na nowo, wpierw musi zostać unicestwiony 5 .

Wierzono, że aby powstało coś nowego, to co stare musi zostać zburzone. Agresja fazy liminalnej służy rozbiciu w proch tego, co było przed inicjacją. Inicjacja to rytualna śmierć jednej tożsamości i narodziny nowej. Rytuały inicjacyjne mają pokazywać neoficie jego niewiedzę, sprawdzać

${ }^{1}$ A. van Gennep, Obrzędy przejścia. Systematyczne studium ceremonii, przekł. B. Biały, Warszawa 2006, s. 37.

2 Tamże, s. 45.

${ }^{3}$ Tamże.

${ }^{4}$ V. Turner, Liminalność i communitas, przekł. E. Dżurak, [w:] Badanie kultury. Elementy teorii antropologicznej. Kontynuacje, red. M. Kempy, E. Nowicka, Warszawa 2006, s. 241.

${ }_{5}^{5}$ M. Eliade, Inicjacja, obrzędy, stowarzyszenia tajemne. Narodziny mistyczne, przekł. K. Kocjan, Kraków 1997, s. 10-11.

${ }^{6}$ V. Turner, Proces rytualny. Struktura i antystruktura, przekł. E. Dżurak, Warszawa 2010, s. 122.

${ }^{7}$ M. Eliade, Inicjacja, obrzędy, stowarzyszenia tajemne. 
zaradność i wystawiać na próbę wierność nowej grupie ${ }^{8}$. Adepci byli w tym celu pozbawiani praw, okaleczani, głodzeni. Nie ma tu miejsca na szczegółową analizę zwyczajów choćby jednego z plemion opisywanych przez antropologów, nie można jednak ze względu na cel tego tekstu pominąć pewnej refleksji związanej z tym, że każde działanie obrzędowe miało swoje symboliczne znaczenie. Na przykład, restrykcje żywieniowe u plemion, których zwyczaje przywołałam za Eliade na początku tekstu, miały charakter ćwiczeń ascetycznych. Brak snu uczył bycia świadomym i obecnym, a wybijanie zębów symbolizowało pożarcie przez potwora (a tylko pożarcie i strawienie pozwalało zmartwychwstać do nowego życia) ${ }^{9}$. Poza symbolicznym wymiarem działań obrzędowych plemienne rytuały inicjacyjne miały także inne wspólne cechy. Zaliczyć można do nich na pewno to, że wejście do dorosłości było bardzo konkretnym punktem w czasie. Niezależnie, czy trwało dobę czy kilka tygodni, młody człowiek dokładnie wiedział, kiedy przekroczy próg dorosłości. Kiedy to się stało, i jest to kolejna cecha rytuału inicjacyjnego, nikt nie kwestionował zmienionego stanu nowicjusza. Sam inicjowany nie miał też wątpliwości, że zmiana zaszła, czemu służyła nie tylko powtarzalność rytuału, ale także jego intensywność. Inicjacja zachodziła w ideologicznych ramach wspólnoty, to znaczy oparta na znanych, pewnych wartościach, jasnych wytycznych. Wiadomo było, skąd, dokąd i po co idzie młody człowiek. Procesowi stawania się dorosłym przewodniczyli i towarzyszyli członkowie wspólnoty, w tym (lub głównie) starszyzna, którzy zewnętrznie organizowali przebieg inicjacji, co pozwalało inicjowanemu tylko poddać się rytuałowi, bez konieczności jego organizowania i refleksji, czy wszystko przebiega prawidłowo. Oczywiście, można znaleźć wady każdego z tych punktów. Przecież rytuał taki indoktrynuje, odbiera wolność decydowania o sobie, odziera $\mathrm{z}$ indywidualizmu, a do tego wszystkiego w swojej intensywności bywa bolesny i okrutny. Jednocześnie jednak rytuał zabezpieczał trudny czas przejścia wiedzą i doświadczeniem wspólnoty. Przemoc rytuałów inicjacyjnych poddawana jest współcześnie krytyce z punktu widzenia etyki i praw człowieka czy medycyny, a w dyskursie wokół tego problemu pojawiają się bardzo zróżnicowane głosy ${ }^{10}$. Należy

${ }^{8}$ K. Konecki, Nowi pracownicy a kultura organizacyjna przedsiębiorstwa. Studium folkloru fabrycznego, Łódź 2007, s. 63.

${ }^{9}$ M. Eliade, Inicjacja, obrzędy, stowarzyszenia tajemne, s. 33.

10 Zob. np. A.J. Jacobs, K.S. Arora, Ritual Male Infant Circumcision and Human Rights, American Journal of Bioethics, 2015, 15, 2; E. Bartels, Medical ethics and rites involving blood, Anthropology and Medicine, 2003, 10, 1; S. Burgess, S.J. Murray, Cutting Both Ways: On the Ethical Entanglements of Human Rights, Rites, and Genital Mutilation, American Journal of Bioethics, $2015,15,2$. 
zatem podkreślić, biorąc pod uwagę te słusznie artykułowane głosy krytyczne, że jednoznaczny wniosek o zabezpieczającej roli rytuału możliwy jest jedynie w warstwie symbolicznej, bowiem w warstwie „fabularnej” rytuał nierzadko jest spektaklem przemocy i odzierania z godności, który co prawda w końcowej scenie przywraca ład, a właściwie buduje ład nowy, ale budzi wiele wątpliwości.

Obecnie młodzież nie doświadcza rytualnej inicjacji, jaką znamy z opisów antropologów. Ramy dzieciństwa i dorosłości nie są jasno sprecyzowane, zmieniają się zadania rozwojowe i czas ich realizacji, ani cezura czasowa, ani inne wskaźniki zmieniającego się statusu nie są wspólne dla wszystkich dorastających ${ }^{11}$. Współczesne rytuały przejścia są jakby rozmyte: w czasie, intensywności, czy mocy sprawczej. Młodzi ludzie są w swoim dorastaniu pozostawieni sami sobie, to na nich spoczywa ciężar zorganizowania sobie swojego dorastania. Muszą sprostać wymaganiom, które stawia przez nimi dominująca $\mathrm{w}$ danym miejscu i czasie kultura, ale $\mathrm{w}$ dużej mierze muszą sobie poradzić z tym wyzwaniem sami.

Ich quasi-inicjacja odbywa się (...) bez przewodnika, bez gotowego wzoru życia i ma często charakter nieświadomy. Nieraz na obrzeżach kultury, ulegając modom i współczesnym nurtom, uobecniają inicjacyjne scenariusze ${ }^{12}$.

Mówi się obecnie, nie tylko w odniesieniu do obrzędów inicjacyjnych, ale do rytuałów w ogóle, że w wyniku postępującej sekularyzacji społeczeństw i takich cech współczesności jak indywidualizacja następuje odrytualnienie rzeczywistości ${ }^{13}$. Nie zanika jednak pragnienie doświadczeń rytualnych, które jest realizowane $\mathrm{w}$ rozmaitych formach, jak na przykład teatr, o czym pisał już Victor Turner ${ }^{14}$. Pojawia się potrzeba, by poprzez sztukę przezwyciężyć poczucie społecznej i jednostkowej fragmentacji15. Ludzie

11 Zob. np. J. Arnett, Emerging Adulthood: What Is It, and What Is It Good For?, Child Development Perspectives, 2007, 1, 2, s. 70; M. Czerwińska-Jasiewicz, Psychologia rozwoju młodzieży w kontekście biegu ludzkiego życia, Warszawa 2015, s. 32-34; A. Oleszkiewicz, A. Senejko, Psychologia dorastania. Zmiany rozwojowe w dobie globalizacji, Warszawa 2013, s. 18-24.

$12 \mathrm{~W}$. Zagórska, Uczestnictwo młodych dorostych w rzeczywistości wykreowanej kulturowo. Doświadczenia, funkcje psychologiczne, Kraków 2004, s. 58.

13 Zob. np. M. Rajewski, Badania rytuatu w antropologii brytyjskiej, [w:] Rytuał. Przeszłość i teraźniejszość, red. M. Filipiak, M. Rajewski, Lublin 2006, s. 56.

14 Zob. np. V. Turner, Od rytuatu do teatru: powaga zabawy, przekł. M. Dziekan, J. Dziekan, Warszawa 2005; tegoż, Liminalność i gatunki performatywne, przekł. K. Przyłuska-Urbanowicz [w:] Rytuat, dramat, święto, spektakl. Wstęp do teorii widowiska kulturowego, red. J.J. MacAloon, Warszawa 2009.

${ }^{15}$ R. Schechner, Performatyka. Wstęp, przekł. T. Kubikowski, Wrocław 2006, s. 102. 
dostarczają sobie rytuałów także poprzez sport, w tym ekstremalny, poprzez podróże, turystykę 16 .

Autorzy upatrujący $\mathrm{w}$ instytucjonalnej "fali” cech rytualnych pokazują, że te rówieśnicze obrzędy inicjacyjne są także próbą wypełnienia istniejącej luki. Pasowanie na ucznia, szkolna akademia czy apel nie realizują inicjacyjnych potrzeb, więc młodzi ludzie inicjują się sami. Jak zauważa Kazimierz Pospiszyl,

brak surowości i mdła otoczka emocjonalna większości współczesnych oficjalnych rytuałów inicjacyjnych wyrównywane bywają dużym ładunkiem brutalności i okrucieństwa rytuałów inicjacyjnych nieoficjalnych ${ }^{17}$.

Czy jednak falę możemy rzeczywiście nazwać szkolnym rytuałem?

Przemoc starszych (wiekiem lub stażem) członków społeczności zawodowych, edukacyjnych czy innych instytucji nie jest ani zjawiskiem nowym, ani rzadkim. Na przykład, z obszernych badań Krzysztofa Koneckiego, prowadzonych w latach osiemdziesiątych ubiegłego wieku w dużym zakładzie produkcyjnym, wynikało, że średnio mijają cztery tygodnie zanim nowy pracownik zostanie zaakceptowany $\mathrm{w}$ miejscu pracy ${ }^{18}$. W tychże badaniach Koneckiego jednym z ważniejszych elementów procesu wyznaczania pozycji społecznej w grupie nieformalnej pracowników zakładu produkcyjnego oraz sposobem inicjowania nowych pracowników są rytuały ośmieszania ${ }^{19}$. „Fala” najbardziej typowa jest jednak dla instytucji totalnych, takich jak wojsko i to stąd przeniknęła do szkół ${ }^{20}$. Szkolną "falę" łączy się z przyjmowaniem „pierwszoklasistów - >kotów< - do społeczności uczniowskiej przez uczniów klas starszych w sposób nieformalny, często

${ }^{16}$ Zob. np. J. Hańderek, Kulturowe wymiary podróżowania, Folia Turistica. Filozofia podróży i turystyki, 2011, 24; M. Kazimierczak, W poszukiwaniu praktycznej filozofii podróży, Folia Turistica. Filozofia podróży i turystyki, 2011, 24; A. Matthews, Backpacking as a Contemporary Rite of Passage: Victor Turner and Youth Travel Practices, [w:] Victor Turner and Contemporary Cultural Performance, red. G. St John, New York 2008; V. Turner, Liminal to Liminoid, in Play, Flow, and Ritual: An Essay in Comparative Symbology, Rice University Studies, 1974, 60, s. 85; V. Turner, E. Turner, Obraz i pielgrzymka w kulturze chrześcijańskiej, przekł. E. Klekot, Kraków 2005; V. Turner, Gry społeczne, pola i metafory. Symboliczne dziatanie w społeczeństwie, przekł. W. Usakiewicz, Kraków 2005; A. Ziębińska-Witek, Turystyka śmierci jako zjawisko kulturowe, Teksty Drugie: teoria literatury, krytyka, interpretacja, 2012, 3(135).

${ }^{17}$ K. Pospiszyl, Flety i fala. Geneza i przemiany rytuałów inicjacyjnych, Psychologia Wychowawcza, 1998, 3, s. 264.

${ }^{18} \mathrm{~K}$. Konecki, Nowi pracownicy a kultura organizacyjna przedsiębiorstwa, s. 43.

19 Tamże, s. 59.

20 I. Siudem, Fala w szkole. Analiza zjawiska, Annales Universitatis Mariae Curie-Skłodowska, Sectio J., 2004, XVII, s. 135. 
przy użyciu siły i przemocy"21. Formy upokarzania nowych uczniów przez uczniów starszych są różne. Marek Siudem stopniuje je

od prostych, niczym niegrożących zadań, np. recytowanie humorystycznych wierszy, do różnych upokarzających czynności z zadawaniem bólu fizycznego włącznie. Można tu wymienić m.in.: zamiatanie piórkiem korytarza szkolnego, utrudnianie załatwiania potrzeb fizjologicznych (...), wkładanie głowy pierwszoklasisty do wypełnionej muszli klozetowej i spłukiwanie wody (...), smarowanie pierwszoklasisty jego własnymi lub cudzymi ekskrementami (...), bicie, kopanie (...), skłanianie do jedzenia pokarmu przeznaczonego dla kotów (...), zmuszanie do oddawania pieniędzy lub innych przedmiotów (...), podrzucanie pierwszoklasistą tak, by uderzał o sufit 22 .

O aktualności problemu szkolnej „fali” przekonałam się kilka miesięcy temu, kiedy przeprowadziłam wśród studentów sondaż diagnostyczny na temat zwyczajów związanych z rozpoczęciem roku szkolnego w ich szkołach $^{23}$. Spodziewałam się opisów ceremonii pasowania na pierwszoklasistę i oficjalnych "chrztów”, a oprócz nich zebrałam bardzo dużo wypowiedzi o szkolnej „fali”, szczególnie w gimnazjum. Oto kilka cytatów24:

W moim gimnazjum była "fala" (...). Ciągły strach, że "fala" mnie dopadnie.

Nie bratem w nich udziatu, ale mówiło się, że trzeba np. mierzyć zapatką boisko albo czyścić toalety szczoteczka do zębów.

Byłem przerażony, że może mnie to spotkać, ponieważ byłem ofiara szkolnej przemocy.

Dokuczanie, kręujace "wyzwania" itp.

Jedynie w gimnazjum był taki zwyczaj witania pierwszych klas, mówiono o tym „kocenie”. Często starsi uczniowie w taki sposób prześladowali młodszych.

Starsi wymyślali różne zadania tym młodszym uczniom, bywały upokarzające.

${ }^{21}$ A. Leszczyńska, „Drugie życie szkoty” - przemoc czy szkolny rytuał? Uwagi pedagoga, [w:] Przemoc dzieci i młodzieży, red. J. Papież, A. Płukis, Toruń 1999, s. 320.

22 I. Siudem, Fala w szkole. Analiza zjawiska, s. 136.

${ }^{23}$ Badanie przeprowadzone w 2016 roku drogą elektroniczną poprzez formularz Google rozesłany studentom Uniwersytetu im. Adama Mickiewicza w Poznaniu oraz Akademii im. Jana Długosza w Częstochowie. Liczebność próby: 217 osób. Dziękuję za pomoc w organizowaniu próby badawczej mgr Karolowi Motylowi z AJD w Częstochowie.

${ }^{24}$ Zapis oryginalny. 
Mierzenie zapałka korytarza, ptukanka głowy w muszli klozetowej. (Czułam, S.J.) złość na oprawców i niemoc jeżeli chodzi o pomoc ofierze.

Kazali mierzyć schody zapałka wyrzucali rzeczy z plecaka.

Te nieoficjalne (zwyczaje, S.J.) w szkole - fala, bolesne, niekontrolowane a wcią̇ powszednie.

W gimnazjum polegało to bardziej na zasadzie gnębienia przez starsze roczniki (zdarzyło się nawet, że ktoś zmuszał do palenia papierosów, obnażania się itp.) (...) Towarzyszył mi przede wszystkim strach i złość, że na mnie trafito.

Kocenie (w gimnazjum, S.J.) nie byto zbyt przyjemne, bo było zbyt nachalne, (...) (czuliśmy, S.J.) strach, bo nikt nie chciał być popisany flamastrem.

W szkole było kotowanie oficjalne $i$ "nieoficjalne". Kotowanie oficjalne, czyli takie pod okiem nauczycieli, wesote, śmieszne konkurencje między klasami (liceum). I kotowanie nieoficjalne (to pamiętam $z$ gimnazjum), odbywało się w szkolnych toaletach, chodziło o upokarzanie nowych uczniów.

Przykłady takie, jak mierzenie szczoteczką korytarza czy "wycug” w toalecie wskazują na "wojskowe inspiracje” szkolnej fali. Pedagodzy zajmujący się tym zjawiskiem szukają jednak także innych jej źródeł. Falę traktuje się na przykład jako młodzieżową popkulturę, doszukując się ideologii leżącej u podstaw tego zjawiska ${ }^{25}$. Dręczyciele mają swoich przywódców i strukturę ${ }^{26}$. Ciekawe jest opisywane przez Ireneusza Siudema zjawisko rytuału inicjacyjnego fundowane nowym członkom grupy dręczycieli. Aby stać się członkiem grupy inicjujących $\mathrm{w}$ okrutny sposób, samemu trzeba przejść rytuał inicjacji27. Zgadzam się z Siudemem, który pokazuje, że nawet mimo tych cech, które pozwalają postrzegać „falę" jako subkulturę, dręczenie kotów nią nie jest ${ }^{28}$. „Fala” ma charakter sezonowy (początek roku szkolnego) i jest relacyjna (nie istnieje bez ofiar), nie jest to zatem subkultura oprawców, ale ograniczone w czasie zjawisko w relacji pierwszoklasistów i uczniów starszych.

\footnotetext{
${ }^{25}$ I. Siudem, Fala w szkole. Analiza zjawiska, s. 135.

${ }^{26}$ Tamże, s. 137.

27 Tamże, s. 138.

${ }^{28}$ Tamże, s. 139.
} 
W innych ujęciach "fali" szuka się cech dręczycieli i ofiar, próbując tłumaczyć to zjawisko $\mathrm{w}$ kontekście prawidłowości psychologicznych i determinant środowiskowych ${ }^{29}$. Ta perspektywa pozwala rozpatrywać falę jako typową relację osób łatwo wchodzących w rolę agresora i mających skłonność do bycia w roli ofiary, a sytuacja początku nauki w szkole staje się tylko pretekstem. Takiemu ujmowaniu zjawiska przeczą jednak te badania nad szkolną falą, których wnioski wskazują raczej na błędne koło przemocy jako źródło kociarstwa szkolnego ${ }^{30}$. Ireneusz Siudem, Teresa Sołtysiak i Janusz Mąka wymieniają jako podstawowe przyczyny dręczenia po pierwsze fakt, że jest taki zwyczaj, po drugie - odwet za kocenie, którego się samemu doświadczyło, po trzecie dopiero - chęć zaimponowania rówieśnikom czy okazja do zabawy ${ }^{31}$. Jeśli spojrzymy także na wyniki innych badań, z których wynika, że $70 \%$ agresorów było ofiarami kocenia ${ }^{32}$, teza o cechach predestynujących do roli Kota i Dziadka nie może być przyjęta. Z badań Anny Leszczyńskiej wynika na przykład, że „Dziadkiem” może być każdy: „wzorowy uczeń, uczeń popularny w szkole czy też uczeń przeciętny, któremu podoba się przemoc i kocenie" ${ }^{\prime 3}$. Zwykle powodem, dla którego ktoś przyjmuje rolę agresora jest to, że sam był kotem. Gdyby tylko słabe, zalęknione osoby wchodziły w rolę kota, czy tak łatwo stawałyby się członkami kocącej bandy w kolejnym roku? Jest tu jakaś nieścisłość. Ofiary stają się oprawcami nie dlatego, że mają skłonność do przemocy, ale dlatego, że chcą się odegrać za to, czego same doświadczyły.

Obok wyjaśnień „fali” zestawiających ją z działalnością subkultur czy tych poszukujących czynników odpowiedzialnych za występowanie zjawiska, w cechach uczniów pojawiają się także wyjaśnienia traktujące falę jako szkolny zwyczaj/rytuał. Prześledźmy tę tezę krytycznie.

Przypomnijmy za Eliade:

${ }^{29}$ T. Sołtysiak, J. Mąka, "Szykanowanie kotów” - szkolne zwyczaje czy inne uwarunkowania zjawiska? (doniesienie z badań), [w:] Zjawiska patologii społecznej: uwarunkowania, rozmiary profilaktyka prognozy - materiały Ogólnopolskiej Konferencji zorganizowanej przez Katedrę Pedagogiki Specjalnej Wyższej Szkoły Pedagogicznej w Bydgoszczy w dniach 8-9 maja 1995 r., red. T. Sołtysiak, Bydgoszcz 1995, s. 97-105.

${ }^{30}$ A. Kurcz, Młodzież wobec "fali przemocy" w szkole, [w:] Wymiary dzieciństwa. Problemy dziecka $i$ dzieciństwa w zmieniającym się społeczeństwie, red. J. Bińczycka, B. Smoliśka-Theiss, Kraków 2005, s. 147.

${ }^{31}$ I. Siudem, Fala w szkole. Analiza zjawiska, s. 138; T. Sołtysiak, J. Mąka, „Szykanowanie kotów", s. 102.

32 I. Siudem, Fala w szkole. Analiza zjawiska, s. 143.

${ }^{33}$ A. Leszczyńska, "Drugie życie szkoty" - przemoc czy szkolny rytuat? Uwagi pedagoga, [w:] Przemoc dzieci i młodzieży w perspektywie polskiej transformacji ustrojowej, red. J. Papież, A. Płukis, Torun 1999, s. 329. 
przez inicjację rozumie się zespół obrzędów i pouczeń ustnych zmierzających do radykalnej modyfikacji statusu religijnego i społecznego inicjowanego podmiotu (...). Po zakończeniu swych prób neofita cieszy się egzystencją zupełnie inną niż przed inicjacją: stał się innym (...). Obrzędy przejścia - tam, gdzie istnieją - są obowiązkowe dla wszystkich młodych członków plemienia. Aby mieć prawo zostania dopuszczonym między dorosłych, młodzieniec musi stawić czoła wielu próbom inicjacyjnym ${ }^{34}$.

Schemat rytualny realizują zatem te społeczności, w których każdy adept doświadcza obrzędowej inicjacji i gdzie przejście do nowego statusu jest obwarowane obowiązkiem inicjacyjnym. Ponadto, o czym była wyżej mowa, jedną z cech rytuałów jest ich czytelna lokalizacja w czasie - wiadomo kiedy rytuał się rozpoczyna i kiedy kończy. Po pomyślnym zakończeniu zaś nikt nie podważa zmiany statusu neofity. Nie są to cechy szkolnej fali. Reasumując, w szkole nie każdy nowy uczeń jest kocony. Rytuał inicjacyjny nie jest konieczny, aby status się zmienił. Obrzędy nieformalne nie są też konkretnie usytuowane w czasie, nie wiadomo, kiedy się zakończą i nie ich zakończenie decyduje o zmianie statusu, ale przejście do klasy wyższej, czyli naturalna kolej rzeczy.

Bliższe rytuałom przejścia są inne edukacyjne zwyczaje inicjacyjne, mianowicie te, które organizują bractwa studenckie. Opisując tego typu zjawiska w Ameryce Robert Caldini podkreśla, że

sprawcy dręczenia nowicjuszy jawią się (...) jako ludzie normalni, psychicznie zdrowi i zaangażowani społecznie, którzy $\mathrm{w}$ jednym tylko momencie zdradzają „sadystyczne objawy" - w momencie przyjmowania nowych członków do własnej grupy ${ }^{35}$.

Podobnie $\mathrm{w}$ plemiennych rytuałach inicjacyjnych przemoc wobec adeptów nie była spowodowana sadystycznymi skłonnościami starszyzny, ale zwyczajem obowiązującym we wspólnocie. Skoro o starszyźnie mowa, warto w tym miejscu zauważyć, że w przypadku szkolnej "fali” oraz inicjacji studenckich różnica wieku między kotami a mistrzami jest niewielka, co jak zauważa Kazimierz Pospiszyl, skutkuje potrzebą eksponowania prestiżu. Agresja musi być większa, żeby nie było wątpliwości, kto zawiaduje sytuacją, sam wiek nie jest bowiem czynnikiem wystarczającym ${ }^{36}$. Zarówno rytuały inicjacyjne społeczności plemiennych, jak i te w bractwach studenckich służą przekazowi wartości obowiązujących w grupie i wzmocnieniu zaangażowania w jej sprawy. Badania, które przywołuje Caldini pokazują, że

${ }^{34}$ M. Eliade, Inicjacja, obrzędy, stowarzyszenia tajemne, s. 8.

${ }^{35}$ R. Caldini, Wywieranie wptywu na ludzi. Teoria i praktyka, przekł. B. Wojciszke, Gdańsk 2014, s. 91.

${ }^{36}$ K. Pospiszyl, Flety i fala, s. 265. 
osoby inicjowane do różnych grup w "mocniejszy” sposób bardziej się potem $\mathrm{z}$ tymi grupami identyfikują ${ }^{37}$. Nie jest to motyw typowy dla szkolnej „fali". Czy bowiem po ukończonym rytuale starsi uczniowie ciepło witają neofitów w swojej społeczności? Nie spotkałam takich historii w opowieściach o koceniu w szkole. Także żaden $\mathrm{z}$ badanych przeze mnie studentów nie uznał, że "fala" sprawiła, iż czuł się częścią wspólnoty. Oczywiście, o czym już pisałam, przejście do klas starszych upoważnia do bycia po drugiej stronie i do kotowania innych, nie czyni jednak tego samo kotowanie, rytuał nie ma więc wszystkich opisanych przez van Gennepa faz. Brakuje fazy włączenia, bez której dwie pozostałe tracą sens. O ile więc w odniesieniu do bractw studenckich można powiedzieć, że rytuały inicjacyjne służą przetrwaniu i potwierdzeniu grupy, nie ma to zastosowania wobec problemu szkolnej fali. Ta konstatacja zbliża traktowanie kociarstwa raczej jako zjawiska, które tylko naśladuje rytuały inicjacyjne, służąc jednak innym celom. Jakim? Niektórzy uważają, że jest to po prostu jedna z form szkolnej przemocy. Pisałam o tym wyżej, a teraz wracam do tego wątku, by dokładniej mu się przyjrzeć.

Anna Leszczyńska pyta w tytule swojego tekstu: Drugie życie szkoty przemoc czy szkolny rytuat? ${ }^{38}$ zakładając ich rozdzielność. Autorka nie daje wprost odpowiedzi na to pytanie, ale z tekstu i rekomendacji go kończących wynika, że i to, i to, bowiem przemoc jest $\mathrm{w}$ rytuał inicjacyjny wpisana. Fizyczna i psychiczna dotkliwość rytuałów inicjacyjnych ma przynamniej kilka uzasadnień. O dwóch już wspominałam: jedno dotyczy odzierania z tożsamości ${ }^{39}$, drugie służy wzmacnianiu zaangażowania. Przemoc osłabia adeptów danej wspólnoty, mocno wskazuje obowiązujące zasady, przestrzega przed ich łamaniem i daje poczucie wdzięczności kiedy rytuał się kończy oraz wzmaga zaangażowanie. Trzecie uzasadnienie, które $\mathrm{w}$ tym miejscu przywołam, staje zupełnie w opozycji do tytułu tekstu Leszczyńskiej. Weźmy poglądy Rene Girarda. Zaliczany jest on do zwolenników tezy, że $\mathrm{w}$ rytuale zawsze kryje się przemoc ${ }^{40}$. Według tego autora, rytuał można rozpoznać wśród innych społecznych technik symbolicznych po roli, jaką pełni w oddalaniu i odraczaniu przemocy, która jest nieuchronna ${ }^{41}$. Oddalić przemoc na dużą skalę można odgrywając przemoc w rytuale i tym samym zaspokajając przemocową potrzebę społeczności. $W$ takiej perspektywie

${ }^{37}$ R. Caldini, Wywieranie wptywu na ludzi, s. 92.

38 A. Leszczyńska, "Drugie życie szkoty” - przemoc czy szkolny rytuat?

${ }^{39} \mathrm{M}$. Eliade, Inicjacja, obrzędy, stowarzyszenia tajemne.

${ }^{40}$ F. Bowie, Antropologia religii. Wprowadzenie, przekł. K. Pawluś, Kraków 2008, s. 176.

${ }^{41}$ M. Kociuba, Geneza rytuatu w kontekście antropologii Rene Girarda, [w:] Rytuat. Przeszłość i teraźniejszość, s. 74. 
adepci są niebezpieczni, bo robią wyłom w zasadach codzienności i trzeba zapobiegawczo potraktować ich przemocą, bo sami mogą przynieść przemoc lub propozycję zmiany reguł. Moc rytuału polega na tym, że "społeczeństwo stara się skierować przemoc na ofiarę względnie obojętną, która ma być >poświęcona $<$, aby w ten sposób uchronić swoich własnych członków"42. Jeśli zakładamy, że przemoc i rytuał nie są rozdzielne, a nawet przyjmujemy za Girardem, że przemoc jest stałym elementem rytuału, wówczas pytanie brzmiałoby: drugie życie szkoły - przemoc rytualna czy nierytualna? Ale jak ma brzmieć odpowiedź? Rytuał czy nie-rytuał? Zdaje się, że przemoc szkolnej „fali” nie pełni żadnej z wymienionych wyżej ról. To kolejny punkt oddalający ją do rytuału - przemoc jest, ale ani nie przemienia, zdaje się nie być nośnikiem symboli (przekaz jest dosłowny i dotyczy miejsca w strukturze uczniów nowych i starszych stażem), ani nie zabezpiecza przed niczym społeczności.

Po analizie dostępnych wyników badań na temat "fali" w szkole i zestawieniu ich z teorią rytuałów przejścia blisko jest mi do przyjęcia założenia, że "fala" szkolna nosi znamiona rytuału przejścia, ale jest od niego bardziej oddalona niż tego rodzaju działania na przykład $\mathrm{w}$ bractwach studenckich, które rzeczywiście wprowadzają w ten sposób do czegoś. Właściwie każdy z rytualnych elementów odbija się w szkolnej "fali” jak w krzywym zwierciadle. Skąd zatem i po co to zapożyczenie, a może lepiej „wrogie przejęcie" rytualnej formy z odarciem jej z rytualnego sensu? Albo rytuał jest potrzebny i to wyraz tęsknoty za nim, albo sytuacja szkolnej inicjacji została wykorzystana w służbie szkolnej agresji. Siudem stawia hipotezę, że być może wobec zjawisk patologizacji różnych sfer życia młodzieży „profanacji uległy także rytuały inicjacyjne, choćby takie jak poczciwe otrzęsiny"43. Ta perspektywa kazałaby nazywać falę zjawiskiem zawłaszczania rytuałów inicjacyjnych do celów nie służących wspólnocie tylko partykularnym celom jednostek, a cele te związane są $w$ działalnością przemocową i odwetową. Niestandardowy w porównaniu $\mathrm{z}$ innymi epizodami przemocowymi skład grup agresorów i ofiar sugeruje też, że forma rytualna angażuje w działania agresywne także te osoby, które w innych warunkach nie byłyby ani agresorami, ani ofiarami. Zatem, szkolne "przejęcie” rytuału inicjacyjnego staje się powodem eskalacji agresji.

Być może dlatego właśnie, że zjawisko "fali" szkolnej jest na tyle skomplikowane i skupiające w sobie wiele czynników jest tak mała spójność między diagnozowanym stanem rzeczy a wskazaniami dla praktyki pedago-

42 R. Girard, Sacrum i przemoc, przekł. M. Plecińska, Poznań 1993, s. 7.

${ }^{43}$ I. Siudem, Fala w szkole. Analiza zjawiska, s. 144. 
gicznej. Na przykład, uczniowie badani przez Leszczyńską podają takie rytualne powody stosowania przemocy wobec nowych, jak: „jeśli zaczynają się stawiać, to trzeba stosować, żeby ich uspokoić”, "bo są kotami i muszą bać się klas starszych", "to nic strasznego, to przyzwyczajanie do życia w szkole”, "wszyscy tępili i dlatego ja tępiłem"44. Autorka stwierdza zaś: „kot staje się symbolicznym uosobieniem świata dorosłych, stosując wobec niego przemoc starsi uczniowie realizują swój bunt przeciwko dorosłym nauczycielom i rodzicom" 45 . Trudno się doszukać wytłumaczenia takiej hipotezy, a gdyby chcieć wyprowadzić z niej rekomendacje dla pracy pedagogicznej, mogłyby one okazać się chybione. Wśród badanych przez Alicję Kucz uczniów szkół ponadgimnazjalnych aż 53\% wchodzi w rolę agresora, bo kiedyś sami tego doświadczyli, 31\% uważa to za pewną szkolną tradycję, której pozostają wierni, a tylko $14 \%$ chce zaimponować w ten sposób kolegom $^{46}$. Kilka stron wcześniej autorka zauważa, że „fala" szkolna nie poddaje się łatwo działaniom korygującym i represyjnym, bo występuje w postaci szkolnego obyczaju ${ }^{47}$. W podsumowaniu zaś pisze, że skuteczne przeciwdziałanie "fali" uwarunkowane jest

dokonaniem rzetelnej diagnozy sytuacji w szkole, wczesnego rozpoznawania pierwszych symptomów pojawienia się przemocy ze strony oprawców, jak i jej ofiar oraz wdrażania programów profilaktycznych, angażujących nie tylko nauczycieli, ale przede wszystkim samą młodzież, jej rodziców i środki masowego przekazu do preferowania wzorów zachowań szanującego godność i niezależność drugiego człowieka ${ }^{48}$.

Te rekomendacje, choć niewątpliwie słuszne, nie współgrają z motywami "kocenia”, mogą więc nie okazać się wystarczające. Więcej niż 8 na 10 badanych przez Kucz uczniów podaje rytualne, wpisane w kulturę szkoły i jej zwyczaje powody kocenia, być może nie chodzi więc o brak szacunku dla godności drugiego człowieka, ale o potrzebę rytuału lub o praktykowanie rytuału przy zagubieniu jego pierwotnych celów? Także Patryk Zawadzki postuluje:

Na samym początku należy przyjrzeć się jakie działania prowadzi szkoła w celu poprawy klimatu społecznego na swoim terenie? Jakie szkolenia powinni przejść nauczyciele w zakresie rozwiązywania problemów młodzieży? Czy warto poszerzać doradztwo pedagogów i psychologów w szkołach? Jakie działania wychowawcze

\footnotetext{
44 A. Leszczyńska, „Drugie życie szkoły” - przemoc czy szkolny rytuat?, s. 329.

45 Tamże, s. 322.

46 A. Kurcz, Młodzież wobec "fali przemocy", s. 150.

47 Tamże, s. 149.

48 Tamże, s. 151.
} 
i porządkowe powinny zostać wprowadzone wobec uczniów stosujących "kocenie"?49

Jeśli kocenie ma charakter rytualny, to czy działania porządkowe wobec stosujących je okażą się skuteczne? W optyce rytualnej porady typu: „profilaktyka powinna oznaczać zapobieganie czynnikom prowadzącym do tworzenia się drugiego, podskórnego życia szkoły" 50 wydają się nie najbardziej trafione, nawet jeśli drogą osiągania tego stanu jest budowanie pozytywnego klimatu ${ }^{51}$. Sposobem uniknięcia w szkole "fali" nie jest też siłowe przejęcie rytuałów przez nauczycieli i próba ich kontrolowania. Robert Caldini opisuje przykład uczelni, której rektor

zarządził, by wszystkie ceremonie inicjacyjne odbywały się dopiero po ich zatwierdzeniu przez specjalną komisję i w obecności jej dorosłych członków. Jak donosiła prasa, nowy regulamin spowodował tak poważne zamieszki w miasteczku uniwersyteckim, że policja miejska i straż pożarna obawiały się wkroczyć na jego teren ${ }^{52}$.

Takie działanie jest rodzajem represji i nie może być skuteczne.

Co zatem można zrobić w sprawie "fali" w szkole, jeśli traktujemy ją jako nieudany/niepełny/wybrakowany rytuał lub rytuał przejęty do realizacji pozarytualnych celów? Skoro uczniowie wchodzą w rolę agresorów, bo sami byli dręczeni i jest to szkolna tradycja, może wypracowanie nowych tradycji pomogłoby $\mathrm{w}$ przerwaniu tego koła? Jak pisze Pospiszyl, nie jest to łatwe, ale

istnieje wiele prób uatrakcyjnienia i udramatyzowania oficjalnych obrzędów inicjacyjnych i tym samym podniesienia ich do rangi żywych obrzędów organizowanych samorzutnie przez młodzież ${ }^{53}$.

Także Leszczyńska wskazuje, że ze względu na rytualną naturę „fali” rozwijanie oficjalnych form inicjowania uczniów i włączanie do niego uczniów starszych może pomóc chociaż w jakimś stopniu ${ }^{54}$. Pytanie, jak to zrobić, aby nie uzyskać wręcz przeciwnego skutku, wymagałoby osobnych analiz we współpracy z nauczycielami-wychowawcami klas. Jedną z propo-

${ }^{49}$ P. Zawadzki, „Fala” w szkole - istota zjawiska i jego uwarunkowania w świetle wyników badań własnych, Wychowanie na co Dzień, 2005, 9, s. 13.

${ }^{50}$ M. Wójcik, „Fala” w szkole, Remedium, grudzień 2010, s. 20.

51 Tamże, s. 20.

52 R. Caldini, Wywieranie wptywu na ludzi, s. 90.

${ }^{53}$ K. Pospiszyl, Flety i fala, s. 268.

54 A. Leszczyńska, „Drugie życie szkoty” - przemoc czy szkolny rytuat?, s. 334. 
zycji może być wykorzystanie w kreowaniu w szkole doświadczeń rytualnych metody dramy55.

Na każde zjawisko można patrzeć z wielu perspektyw, warto konsekwentnie do tej przyjętej stawiać rekomendacje. W temacie szkolnej "fali” jest sporo nieuporządkowania, które jest być może spowodowane pseudorytualnym charakterem "fali", który utrudnia rozpoznanie w niej udziału czynników związanych z samą szkołą oraz cechami ofiar i agresorów. Dominują, jak wynika z badań, uzasadnienia "fali” nawiązujące do jej rytualnego, zwyczajowego miejsca w szkole $\mathrm{i}$ to te jej cechy powinny stanowić odniesienie działań prewencyjnych i naprawczych. Należałoby też nadal badać to zjawisko i szukać możliwych rozwiązań adekwatnych do diagnoz.

\section{BIBLIOGRAFIA}

Arnett J., Emerging Adulthood: What Is It, and What Is It Good For?, Child Development Perspectives, 2007, 1, 2.

Bartels E., Medical ethics and rites involving blood, Anthropology and Medicine, 2003, 10, 1.

Bowie F., Antropologia religii. Wprowadzenie, przekł. K. Pawluś, Wydawnictwo Uniwersytetu Jagiellońskiego, Kraków 2008.

Burgess S., Murray S.J., Cutting Both Ways: On the Ethical Entanglements of Human Rights, Rites, and Genital Mutilation, American Journal of Bioethics, 2015, 15, 2.

Caldini R., Wywieranie wptywu na ludzi. Teoria i praktyka, przekł. B. Wojciszke, Gdańskie Wydawnictwo Psychologiczne, Gdańsk 2014.

Czerwińska-Jasiewicz M., Psychologia rozwoju młodzieży w kontekście biegu ludzkiego życia, Wydawnictwo Difin, Warszawa 2015.

Eliade M., Inicjacja, obrzedy, stowarzyszenia tajemne. Narodziny mistyczne, przekł. K. Kocjan, Społeczny Instytut Wydawniczy „Znak”, Kraków 1997.

Girard R., Sacrum i przemoc, przekł. M. Plecińska, Wydawnictwo Brama, Poznań 1993.

Hańderek J., Kulturowe wymiary podróżowania, Folia Turistica. Filozofia podróży i turystyki", 2011, 24.

Jacobs A.J., Arora K.S., Ritual Male Infant Circumcision and Human Rights, American Journal of Bioethics, 2015, 15, 2.

Jaskulska S., Kreowanie doświadczeń liminalnych w szkole z wykorzystaniem metody dramy edukacyjnej, Studia Edukacyjne, 2016, 42.

Kazimierczak M., W poszukiwaniu praktycznej filozofii podróży, Folia Turistica. Filozofia podróży i turystyki, 2011, 24.

Kociuba M., Geneza rytuału w kontekście antropologii Rene Girarda, [w:] Rytuat. Przeszłość i teraźniejszość, red. M. Filipiak, M. Rajewski, Wydawnictwo Uniwersytetu Marii Curie-Skłodowskiej, Lublin 2006.

Konecki K., Nowi pracownicy a kultura organizacyjna przedsiębiorstwa. Studium folkloru fabrycznego, Wydawnictwo Uniwersytetu Łódzkiego, Łódź 2007.

55 Zob. S. Jaskulska, Kreowanie doświadczeń liminalnych w szkole z wykorzystaniem metody dramy edukacyjnej, Studia Edukacyjne, 2016, 42. 
Kurcz A., Młodzież wobec "fali przemocy" w szkole, [w:] Wymiary dzieciństwa. Problemy dziecka i dzieciństwa w zmieniającym się społeczeństwie, red. J. Bińczycka, B. Smoliśka-Theiss, Oficyna Wydawnicza Impuls, Kraków 2005.

Leszczyńska A., "Drugie życie szkoty" - przemoc czy szkolny rytuat? Uwagi pedagoga, [w:] Przemoc dzieci i młodzieży, red. J. Papież, A. Płukis, Wydawnictwo Adam Marszałek, Torun 1999.

Matthews A., Backpacking as a Contemporary Rite of Passage: Victor Turner and Youth Travel Practices, [w:] Victor Turner and Contemporary Cultural Performance, red. G. St John, Berghahn Books, New York 2008.

Oleszkiewicz A., Senejko A., Psychologia dorastania. Zmiany rozwojowe w dobie globalizacji, Wydawnictwo Naukowe PWN, Warszawa 2013.

Pospiszyl K., Flety i fala. Geneza i przemiany rytuałów inicjacyjnych, Psychologia Wychowawcza, 1998, 3.

Pospiszyl K., Elementy przemocy w rytuałach inicjacyjnych, [w:] Przemoc dzieci i młodzieży w perspektywie polskiej transformacji ustrojowej, red. J. Papież, A. Płukis, Wydawnictwo Adam Marszałek, Torun 1999.

Rajewski M., Badania rytuału w antropologii brytyjskiej, [w:] Rytuał. Przeszłość i teraźniejszość, red. M. Filipiak, M. Rajewski, Wydawnictwo Uniwersytetu Marii Curie-Skłodowskiej, Lublin 2006.

Schechner R., Performatyka. Wstęp, przekł. T. Kubikowski, Ośrodek Badań Twórczości Jerzego Grotowskiego i Poszukiwań Teatralno-Kulturowych, Wrocław 2006.

Siudem I., Fala w szkole. Analiza zjawiska, Annales Universitatis Mariae Curie-Skłodowska, Sectio J., 2004, XVII.

Siudem I., Fala w szkole a poziom i struktura agresji młodzieży, [w:] Agresja w szkole - spojrzenie wieloaspektowe, red. A. Rejzner, Wyższa Szkoła Pedagogiczna im. Janusza Korczaka, Warszawa 2004.

Sołtysiak T., Mąka J., "Szykanowanie kotów” - szkolne zwyczaje czy inne uwarunkowania zjawiska? (doniesienie z badań), [w:] Zjawiska patologii społecznej: uwarunkowania, rozmiary profilaktyka prognozy - materiały Ogólnopolskiej Konferencji zorganizowanej przez Katedrę Pedagogiki Specjalnej Wyższej Szkoły Pedagogicznej w Bydgoszczy 8-9 maja 1995 r., red. T. Sołtysiak, Wydawnictwo WSP w Bydgoszczy, Bydgoszcz 1995.

Turner V., Liminal to Liminoid, in Play, Flow, and Ritual: An Essay in Comparative Symbology, Rice University Studies, 1974, 60.

Turner V., Gry społeczne, pola i metafory. Symboliczne działanie w społeczeństwie, przekł. W. Usakiewicz, Wydawnictwo Uniwersytetu Jagiellońskiego, Kraków 2005.

Turner V., Od rytuatu do teatru: powaga zabawy, przekł. M. Dziekan, J. Dziekan, Oficyna Wydawnicza Volumen, Warszawa 2005.

Turner V., Liminalność i communitas, przekł. E. Dżurak, [w:] Badanie kultury. Elementy teorii antropologicznej. Kontynuacje, red. M. Kempny, E. Nowicka, Wydawnictwo Naukowe PWN, Warszawa 2006.

Turner V., Liminalność i gatunki performatywne, przekł. K. Przyłuska-Urbanowicz [w:] Rytuat, dramat, święto, spektakl. Wstęp do teorii widowiska kulturowego, red. J.J. MacAloon, Wydawnictwa Uniwersytetu Warszawskiego, Warszawa 2009.

Turner V., Proces rytualny. Struktura i antystruktura, przekł. E. Dżurak, Państwowy Instytut Wydawniczy, Warszawa 2010.

Turner V., Turner E., Obraz i pielgrzymka w kulturze chrześcijańskiej, przekł. E. Klekot, Wydawnictwo Uniwersytetu Jagiellońskiego, Kraków 2005.

Wójcik M., „Fala” w szkole, Remedium, grudzień 2010. 
van Gennep A., Obrzędy przejścia. Systematyczne studium ceremonii, przekł. B. Biały, Państwowy Instytut Wydawniczy, Warszawa 2006.

Zagórska W., Uczestnictwo młodych dorostych w rzeczywistości wykreowanej kulturowo. Doświadczenia, funkcje psychologiczne, Towarzystwo Autorów i Wydawców Prac Naukowych Universitas, Kraków 2004.

Zawadzki P., "Fala” w szkole - istota zjawiska i jego uwarunkowania w świetle wyników badań własnych, Wychowanie na co Dzień, 2005, 9.

Ziębińska-Witek A., Turystyka śmierci jako zjawisko kulturowe, Teksty Drugie: teoria literatury, krytyka, interpretacja, 2012, 3(135). 